\title{
Why positive results from protein test strips in urine samples in men can put the patient's health at risk due to over-treatment
}

\author{
Dr. Carolina Diamandis ${ }^{1}$, Yousef $\mathrm{Abbas}^{1}$, and Jonathan Feldman ${ }^{1}$
}

${ }^{1}$ Affiliation not available

November 8, 2021

\begin{abstract}
Testing for microscopic blood traces, protein and other parameters by means of test strips has been a standard method in general medical and urological practices for years, but also in private settings. We report a potential source of error in the measurement of protein content of urine in men which has never been addressed in the manufacturer's instructions or in other publications.
\end{abstract}

\section{Hosted file}

Urine Test Strips V1.pdf available at https://authorea.com/users/410930/articles/544246-whypositive-results-from-protein-test-strips-in-urine-samples-in-men-can-put-the-patients-health-at-risk-due-to-over-treatment 